\title{
Phylogeny of the families Pyuridae and Styelidae (Stolidobranchiata, Ascidiacea) inferred from mitochondrial and nuclear DNA sequences
}

\author{
R. Pérez-Portela ${ }^{\mathrm{a}, \mathrm{b}, *}$, J.D.D. Bishop ${ }^{\mathrm{b}, \mathrm{c}}$, A.R. Davis ${ }^{\mathrm{d}}$, X. Turon ${ }^{\mathrm{e}}$ \\ ${ }^{a}$ Eco-Ethology Research Unit, Instituto Superior de Psicologia Aplicada (ISPA), Rua Jardim do Tabaco, 34, 1149-041 Lisboa, Portugal \\ ${ }^{\mathrm{b}}$ Marine Biological Association of United Kingdom, The Laboratory Citadel Hill, PL1 2PB Plymouth, UK

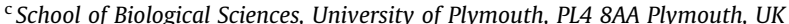 \\ ${ }^{\mathrm{d}}$ School of Biological Sciences, University of Wollongong, Wollongong, NSW 2522, Australia \\ e Centre d'Estudis Avançats de Blanes (CEAB, CSIC), Accés a la Cala St. Francesc 14, Blanes, Girona E-17300, Spain
}

\section{A R T I C L E I N F O}

\section{Article history:}

Received 22 July 2008

Revised 10 November 2008

Accepted 15 November 2008

Available online 27 November 2008

\section{Keywords:}

Pyuridae

Styelidae

Stolidobranchiata

Molecular phylogeny

Coloniality

COI

$18 \mathrm{~S}$ rDNA

\begin{abstract}
A B S T R A C T
The Order Stolidobranchiata comprises the families Pyuridae, Styelidae and Molgulidae. Early molecular data was consistent with monophyly of the Stolidobranchiata and also the Molgulidae. Internal phylogeny and relationships between Styelidae and Pyuridae were inconclusive however. In order to clarify these points we used mitochondrial and nuclear sequences from 31 species of Styelidae and 25 of Pyuridae. Phylogenetic trees recovered the Pyuridae as a monophyletic clade, and their genera appeared as monophyletic with the exception of Pyura. The Styelidae, on the other hand, appeared as a paraphyletic group split into several clades. One of them was formed by solitary oviparous species, of which the Pyuridae were a sister group. A second clade included the colonial genera Botryllus, Botrylloides and Symplegma. The remaining colonial and solitary genera formed several poorly resolved clades. One of the more species genus, Polycarpa, was shown to be polyphyletic, and the species Styela plicata grouped into two genetically distant clades suggesting the existence of two cryptic species. The internal phylogeny of Styelidae has bearings on the origin of coloniality in this family. We suggest to abandon the traditional division of colonial forms into social and compound species and use instead the categories of aggregated colonies that do not have common vascular systems, and integrated colonies, that do possess such systems. Our molecular results indicate that there have been several independent acquisitions of coloniality in the Styelidae, and that viviparity may be a pre-adaptation for a colonial life-style.
\end{abstract}

(c) 2008 Elsevier Inc. All rights reserved.

\section{Introduction}

In the last two decades, molecular techniques have been applied to questions addressing the evolution of the deuterostomes (e.g. Turbeville et al., 1994; Cameron et al., 2000; Swalla et al., 2000; Bourlat et al., 2003; Blair and Hedges, 2005). The phylogeny of the Phylum Chordata, originally divided into three subphyla, Vertebrata, Cephalochordata and Urochordata, has also been intensely studied in order to clarify the mechanisms of chordate evolution (Winchell et al., 2002; Zeng and Swalla, 2005).

New phylogenomic approaches have recently overturned conventional thinking about the relationships within chordates (Philippe et al., 2005; Bourlat et al., 2006; Delsuc et al., 2006; Dunn et al., 2008; Blair and Hedges, 2005). One of the most recent molec-

* Corresponding author. Address: Eco-Ethology Research Unit, Instituto Superior de Psicologia Aplicada (ISPA), Rua Jardim do Tabaco, 34, 1149-041 Lisboa, Portugal. Fax: +351218860954.

E-mail addresses: rportela@ispa.pt, rocio_perez@ub.edu (R. Pérez-Portela), jbis@mba.ac.uk (J.D.D. Bishop), adavis@uow.edu.au (A.R. Davis), xturon@ceab. csic.es (X. Turon). ular phylogenies has suggested that the Subphylum Urochordata (Tunicata), represented by three different classes, Ascidiacea, Thaliacea and Larvacea, should be raised to the phylum level (Zeng and Swalla, 2005) but the subject is still under discussion since there are discrepancies between phylogenomic analyses and results from mitochondrial and rRNA data. Clarifying the phylogeny of Urochordata may be a critical step in understanding the evolution of the chordate body plan as well as the vast morphological and life-style differences within this animal group. Unfortunately, only a few works have addressed particular questions about the internal phylogeny of the Urochordata and, while some interesting relationships such as the inclusion of thaliaceans within ascidians have been uncovered (Swalla et al., 2000; Stach and Turbeville, 2002; Zeng and Swalla, 2005), other important questions, such as the placement of the Appendicularia, remain unresolved (Stach and Turbeville, 2002; Zeng et al., 2006).

The class Ascidiacea comprises three different orders and more than 17 families with a diversity of biological features. For most of these taxa, phylogenetic relationships remain poorly resolved (Turon and López-Legentil, 2004). Within the Ascidiacea, the Order 
Stolidobranchiata is one of the most important groups as it is species and exhibits high morphological plasticity and complexity. To date, molecular and morphological data support the monophyly of the Stolidobranchiata uniting the traditionally recognized families Pyuridae, Styelidae and Molgulidae (Berrill, 1950; Kott, 1985; Monniot et al., 1991; Swalla et al., 2000; Zeng et al., 2006). However, the internal classification of this order remains under discussion. Whereas the Molgulidae has emerged as a well-supported monophyletic family, the relationships among the families Styelidae and Pyuridae have been poorly resolved and the phylogenies obtained inconclusive (Wada et al., 1992; Huber et al., 2000; Stach and Turbeville, 2002; Zeng et al., 2006). There are strong morphogical evidences that Pyuridae and Molgulidae are related, with the latter having probably originated from the former (Berrill, 1950). However, Swalla et al. (2000) showed that the families Pyuridae and Styelidae formed a robust clade, separated from Molgulidae, but with both families being either paraphyletic or polyphyletic. In the molecular phylogeny reconstructed by Zeng et al. (2006), including five pyurids and 12 styelids, the family Pyuridae appeared either as a paraphyletic or a monophyletic group depending on the algorithms of reconstruction applied. Consequently, the relationships and internal phylogeny of these two families are not yet fully resolved.

Styelidae and Pyuridae show great complexity of the general body plan. Styelid body organization in particular has by far the greatest range of variation among ascidians, and styelids can resemble in one way or another species of almost any other family, including both solitary and colonial species as well as intermediate morphologies (Monniot et al., 1991). One currently accepted systematic arrangement of the family comprises three subfamilies, the Styelinae including solitary forms, the Polyzoinae including colonies whose zooids do not form systems, and the Botryllinae grouping colonial species that do form systems (Kott, 1985). On the other hand, the pyurid body plan may well be (together with Molgulidae) the most differentiated among ascidians (Berrill, 1950; Monniot et al., 1991). Pyuridae consists exclusively of simple, usually large, oviparous ascidians. Both styelids and pyurids feature stalked and unstalked forms. Being raised above the substratum on stalks can have important benefits for spatial competition and feeding activity (Young and Braithwaite, 1980; Kott, 1989; Monniot et al., 1991). It is not known whether this adaptation has appeared many times independently or whether there are evolutionary affinities between some or all of the stalked forms within families.

Another key question that can be addressed if a sound phylogenetic framework can be established is the origin of coloniality in Styelidae. Ascidians comprise both solitary and colonial forms. Colonial species include most of the Aplousobranchiata while solitary forms dominate the Phlebobranchiata and Stolidobranchiata. The ancestral ascidian may have been a colonial or a solitary form (Van Name, 1921; Garstang, 1928; Berrill, 1955; Kott, 1985), but it is clear that the colonial life-style in stolidobranchs is independently acquired (Kott, 1985; Wada et al., 1992) and differs from that of aplousobranchs and phlebobranchs in the type of budding and colony structure (Berrill, 1951; Nakauchi, 1982).

Colonial forms, all of them showing both sexual and asexual reproduction, are often divided into social and compound species. This classification, dating back to Milne Edwards (1841), distinguishes between colonies where the zooids are embedded in a common tunic (compound species) and those in which zooids are more or less connected basally but generally retain their individuality (social species). However, this classification is problematic, as there are intermediate forms, even in a single species. From the point of view of colony integration it is more relevant to consider whether zooids posses common vascular connections, which is a hallmark of strong colonial integration and the acquisition of colony specificity (Koyama and Watanabe, 1986; Satoh, 1994; Bishop and Sommerfeldt, 1999). Common vascular systems are found in the phlebobranch Perophoridae (social colonies) and the stolidobranch Botryllinae (compound colonies) (Brien, 1948). Most of the Polyzoinae would qualify as social colonies, and they do not have in general vascular connections between zooids. However, some genera included within Polyzoinae, such as Symplegma and Metandrocarpa, feature common vascular systems (Abbot, 1953; Watanabe and Newberry, 1976; Mukai et al., 1978). The vascular system may be important in clarifying the phylogeny of colonial styelids. We propose to adopt a more biologically meaningful classification of colonial species, with names partly derived from Mukai et al. (1978), into "integrated" colonial forms and "aggregated" colonial forms, depending on the presence or absence of permanent vascular connections among individuals, respectively. Mapping these colonial categories into a phylogenetic scheme might help unravel the evolution of coloniality in the Styelidae. Zeng et al. (2006) obtained results consistent with the appearance of coloniality just once, but their analysis included only three genera of colonial species, and a broader taxonomic sampling is necessary.

Variability and complexity in the body structure of ascidians has frustrated the establishment of clear relationships between families and genera using traditional morphological data. In this sense, molecular analyses provide us with a new and independent source of information for interpretation of the relationships among groups at several taxonomic levels. Phylogenies based on DNA have addressed interesting aspects of ascidian evolution, such as the independent origin of anural larval development within the order Stolidobranchiata (Hadfield et al., 1995; Huber et al., 2000) and the placement of the family Cionidae, previously included in the Phlebobranchiata, within the Aplousobranchiata (Turon and López-Legentil, 2004). Further, these phylogenies have clarified issues regarding some family-level arrangements (e.g. Pérez-Portela and Turon, 2008).

To date 18S rDNA and mtDNA (cytochrome genes) sequences have been the most widely used markers in molecular phylogenies in tunicates (e.g. Wada et al., 1992; Wada, 1998; Swalla et al., 2000; Stach and Turbeville, 2002; Turon and López-Legentil, 2004; Pérez-Portela et al., 2007; Zeng et al., 2006). However, only rarely have both types of marker been combined in a study (Stach and Turbeville, 2002; Zeng et al., 2006). In this work, we have assembled COI mtDNA sequence data along with sequences of the nuclear 18S rDNA to address specific taxonomic and phylogenetic questions about the Styelidae and Pyuridae. Using these two markers and a broader taxonomic sampling than in previous works, our goals were to clarify the relationships and the internal arrangement of Pyuridae and Styelidae and to study the evolutionary relationship between solitary and colonial species in Styelidae. Additionally, we were interested in analyzing the affinities between stalked and unstalked species found within the Styelidae and Pyuridae.

\section{Material and methods}

\subsection{Ascidian samples}

Eighty specimens of ascidians belonging to 17 species of the family Pyuridae and 19 species of Styelidae (Stolidobranchiata) were collected from the Mediterranean Sea, Atlantic, Pacific and Indian Ocean by SCUBA diving (see localities in Table 1). Colonial and solitary ascidians were removed from the tunic and preserved in absolute ethanol at $-20^{\circ} \mathrm{C}$ until processed. We added to these data 
Table 1

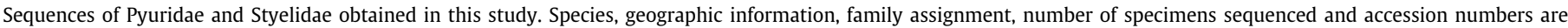
listed.

\begin{tabular}{|c|c|c|c|c|c|c|c|}
\hline Species & Family & Geographic area & Locality & Coordinates & $\mathrm{N}^{\circ}$ ind & COI mtDNA & 18S rDNA \\
\hline Boltenia ovifera & Pyuridae & NW Atlantic & Havre S Pierre, Canada & $50^{\circ} 13^{\prime} 38^{\prime \prime} \mathrm{N}, 63^{\circ} 35^{\prime} 29^{\prime \prime} \mathrm{W}$ & 3 & $\begin{array}{l}\text { FJ528626 } \\
\text { FJ528627 } \\
\text { FJ528628 }\end{array}$ & FM883163 \\
\hline Halocynthia papillosa & Pyuridae & NW Mediterranean & Tossa, Spain & $41^{\circ} 43^{\prime} 17^{\prime \prime} \mathrm{N}, 02^{\circ} 56^{\prime} 25^{\prime \prime} \mathrm{E}$ & 4 & $\begin{array}{l}\text { FJ528606 } \\
\text { FJ528607 } \\
\text { FJ528608 } \\
\text { FJ528609 }\end{array}$ & FM897326 \\
\hline Halocynthia pyriformis & Pyuridae & NW Atlantic & Havre S Pierre, Canada & $50^{\circ} 13^{\prime} 38^{\prime \prime} \mathrm{N}, 63^{\circ} 35^{\prime} 29^{\prime \prime} \mathrm{W}$ & 2 & FJ528610 & FM897327 \\
\hline Herdmania grandis & Pyuridae & SW Pacific & Bass Point, NSW, Australia & $\begin{array}{l}34^{\circ} 35^{\prime} 34^{\prime \prime} \mathrm{S}, 150^{\circ} 53^{\prime} \\
05^{\prime \prime} \mathrm{E}\end{array}$ & 5 & $\begin{array}{l}\text { FJ528629 } \\
\text { FJ528630 }\end{array}$ & FM897328 \\
\hline Herdmania sp. 1 & Pyuridae & W Indian & Shimoni, Kenya & $04^{\circ} 38^{\prime} 59^{\prime \prime} \mathrm{S}, 39^{\circ} 22^{\prime} 28^{\prime \prime} \mathrm{E}$ & 1 & & FM897329 \\
\hline Herdmania sp. 2 & Pyuridae & W Indian & Shimoni, Kenya & $04^{\circ} 43^{\prime} 04^{\prime \prime} \mathrm{S}, 39^{\circ} 22^{\prime} 17^{\prime \prime} \mathrm{E}$ & 1 & & FM897330 \\
\hline Microcosmus claudicans & Pyuridae & NW Mediterranean & Tossa, Spain & $41^{\circ} 43^{\prime} 17^{\prime \prime} \mathrm{N}, 02^{\circ} 56^{\prime} 25^{\prime \prime} \mathrm{E}$ & 1 & FJ528605 & FM897331 \\
\hline Microcosmus polymorphus & Pyuridae & NW Mediterranean & Cubelles, Spain & $41^{\circ} 11^{\prime} 35^{\prime \prime} \mathrm{N}, 01^{\circ} 39^{\prime} 01^{\prime \prime} \mathrm{E}$ & 4 & FJ528604 & FM897332 \\
\hline Microcosmus sabatieri & Pyuridae & NW Mediterranean & Roses, Spain & $42^{\circ} 15^{\prime} 03^{\prime \prime} \mathrm{N}, 03^{\circ} 10^{\prime} 47^{\prime \prime} \mathrm{E}$ & 1 & & FM897333 \\
\hline Microcosmus squamiger & Pyuridae & $\begin{array}{l}\text { NW Mediterranean \& } \\
\text { NE Atlantic }\end{array}$ & $\begin{array}{l}\text { Cubelles, Spain } \\
\text { Barcelona, Spain } \\
\text { San Vicente, Spain }\end{array}$ & $\begin{array}{l}41^{\circ} 11^{\prime} 35^{\prime \prime} \mathrm{N}, 01^{\circ} 39^{\prime} 01^{\prime \prime} \mathrm{E} \\
41^{\circ} 22^{\prime} 29^{\prime \prime} \mathrm{N}, 02^{\circ} 11^{\prime} 01^{\prime \prime} \mathrm{E} \\
43^{\circ} 23^{\prime} 32^{\prime \prime} \mathrm{N}, 04^{\circ} 32^{\prime} 19^{\prime \prime} \mathrm{W}\end{array}$ & 4 & $\begin{array}{l}\text { FJ528603 } \\
\text { FJ528602 } \\
\text { FJ528601 }\end{array}$ & FM897334 \\
\hline Pyura australis & Pyuridae & SW Pacific & Currarong, NSW, Australia & $35^{\circ} 00^{\prime} 29^{\prime \prime} \mathrm{S}, 150^{\circ} 49^{\prime} 37^{\prime \prime} \mathrm{E}$ & 3 & $\begin{array}{l}\text { FJ528616 } \\
\text { FJ528617 }\end{array}$ & $\begin{array}{l}\text { FM897335 } \\
\text { FM897336 }\end{array}$ \\
\hline Pyura dura & Pyuridae & NW Mediterranean & Barcelona, Spain & $41^{\circ} 22^{\prime} 29^{\prime \prime} \mathrm{N}, 02^{\circ} 11^{\prime} 01^{\prime \prime} \mathrm{E}$ & 2 & $\begin{array}{l}\text { FJ528618 } \\
\text { FJ528619 }\end{array}$ & FM897337 \\
\hline Pyura gibbosa & Pyuridae & SW Pacific & Flinders I., NSW, Australia & $34^{\circ} 27^{\prime} 16^{\prime \prime} \mathrm{S}, 150^{\circ} 55^{\prime} 44^{\prime \prime} \mathrm{E}$ & 4 & $\begin{array}{l}\text { FJ528613 } \\
\text { FJ528614 } \\
\text { FJ528615 }\end{array}$ & FM897338 \\
\hline Pyura praeputialis & Pyuridae & SW Pacific & Brisbane, Australia & $27^{\circ} 11^{\prime} 46^{\prime \prime} \mathrm{S}, 153^{\circ} 09^{\prime} 01^{\prime \prime} \mathrm{E}$ & 5 & $\begin{array}{l}\text { FJ528621, } \\
\text { FJ528622, } \\
\text { FJ528623, } \\
\text { FJ528624 }\end{array}$ & $\begin{array}{l}\text { FM897339, } \\
\text { FM897340 }\end{array}$ \\
\hline & & & Wollongong, NSW, Australia & $34^{\circ} 25^{\prime} 05^{\prime \prime} \mathrm{S}, 150^{\circ} 54^{\prime} 12^{\prime \prime} \mathrm{E}$ & & FJ528620 & \\
\hline Pyura squamulosa & Pyuridae & NW Mediterranean & Tossa, Spain & $41^{\circ} 43^{\prime} 17^{\prime \prime} \mathrm{N}, 02^{\circ} 56^{\prime} 25^{\prime \prime} \mathrm{E}$ & 1 & FJ528625 & FM897341 \\
\hline Pyura spinifera & Pyuridae & SW Pacific & Currarong, NSW, Australia & $35^{\circ} 00^{\prime} 29^{\prime \prime} \mathrm{S}, 150^{\circ} 49^{\prime} 37^{\prime \prime} \mathrm{E}$ & 3 & $\begin{array}{l}\text { FJ528611 } \\
\text { FJ528612 }\end{array}$ & FM897342 \\
\hline Pyura sp. & Pyuridae & W Indian & Nyororo, Tanzania & $7^{\circ} 38^{\prime} 41^{\prime \prime} \mathrm{S}, 39^{\circ} 41^{\prime} 58^{\prime \prime} \mathrm{E}$ & 1 & & FM897302 \\
\hline Botryllus schlosseri & Styelidae & $\begin{array}{l}\text { NE Atlantic and NW } \\
\text { Mediterranean }\end{array}$ & $\begin{array}{l}\text { Ferrol, Spain } \\
\text { Tossa, Spain }\end{array}$ & $\begin{array}{l}43^{\circ} 28^{\prime} 45^{\prime \prime} \mathrm{N}, 08^{\circ} 15^{\prime} 34^{\prime \prime} \mathrm{W} \\
41^{\circ} 43^{\prime} 17^{\prime \prime} \mathrm{N}, 02^{\circ} 56^{\prime} 25^{\prime \prime} \mathrm{E}\end{array}$ & 3 & $\begin{array}{l}\text { FJ528642, } \\
\text { FJ528643 } \\
\text { FJ528641 }\end{array}$ & FM897303 \\
\hline Botrylloides leachi & Styelidae & $\begin{array}{l}\text { E Atlantic and NW } \\
\text { Mediterranean }\end{array}$ & $\begin{array}{l}\text { Canary I., Spain } \\
\text { Tossa, Spain }\end{array}$ & $28^{\circ} 07^{\prime} 39^{\prime \prime} \mathrm{N}, 15^{\circ} 25^{\prime} 32^{\prime \prime} \mathrm{W}$ & 2 & FJ528645 & $\begin{array}{l}\text { FM897304, } \\
\text { FM897305 }\end{array}$ \\
\hline Botrylloides violaceum & Styelidae & NE Atlantic & Plymouth, UK & $50^{\circ} 21^{\prime} 18^{\prime \prime} \mathrm{S}, 4^{\circ} 07^{\prime} 35^{\prime \prime} \mathrm{W}$ & 3 & FJ528644 & FM897306 \\
\hline Dendrodoa grossularia & Styelidae & NE Atlantic & Plymouth, UK & $50^{\circ} 21^{\prime} 18^{\prime \prime} \mathrm{S}, 4^{\circ} 07^{\prime} 35^{\prime \prime} \mathrm{W}$ & 5 & $\begin{array}{l}\text { FJ528649 } \\
\text { FJ528650 }\end{array}$ & FM897307 \\
\hline Distomus variolosus & Styelidae & NE Atlantic & Plymouth, UK & $50^{\circ} 21^{\prime} 18^{\prime \prime} \mathrm{S}, 4^{\circ} 07^{\prime} 35^{\prime \prime} \mathrm{W}$ & 3 & $\begin{array}{l}\text { FJ528652 } \\
\text { FJ528653 } \\
\text { FJ528654 }\end{array}$ & FM897308 \\
\hline Eusynstyela hartmeyeri & Styelidae & $\mathrm{N}$ Indian & Eilat, Israel, Red Sea & $29^{\circ} 32^{\prime} 29^{\prime \prime} \mathrm{N}, 34^{\circ} 57^{\prime} 18^{\prime \prime} \mathrm{E}$ & 1 & & FM897309 \\
\hline Polyandrocarpa tincta & Styelidea & E Pacific & Acapulco, Mexico & $16^{\circ} 48^{\prime} 58^{\prime \prime} \mathrm{N}, 99^{\circ} 54^{\prime} 13^{\prime \prime} \mathrm{W}$ & 1 & & FM897310 \\
\hline Polyandrocarpa zorritensis & Styelidae & E Pacific & Acapulco, Mexico & $16^{\circ} 48^{\prime} 58^{\prime \prime} \mathrm{N}, 99^{\circ} 54^{\prime} 13^{\prime \prime} \mathrm{W}$ & 1 & & FM897311 \\
\hline Polycarpa aurata & Styelidae & W Pacific & Sipadan I., Malaysia & $04^{\circ} 06^{\prime} 33^{\prime \prime} \mathrm{N}, 118^{\circ} 37^{\prime} 48^{\prime \prime} \mathrm{E}$ & 1 & FJ528646 & FM897312 \\
\hline Polycarpa tenera & Styelidae & NE Atlantic & Plymouth, UK & $50^{\circ} 21^{\prime} 18^{\prime \prime} \mathrm{S}, 4^{\circ} 07^{\prime} 35^{\prime \prime} \mathrm{W}$ & 5 & FJ528655 & FM897313 \\
\hline Polyzoa opuntia & Styelidae & SW Atlantic & Tierra del Fuego, Argentina & $54^{\circ} 23^{\prime} 17^{\prime \prime} \mathrm{S}, 66^{\circ} 14^{\prime} 04^{\prime \prime} \mathrm{W}$ & 1 & FJ528647 & FM897314 \\
\hline Symplegma rubra & Styelidae & W Indian & Shimoni, Kenya & $04^{\circ} 43^{\prime} 04^{\prime \prime} \mathrm{S}, 39^{\circ} 22^{\prime} 17^{\prime \prime} \mathrm{E}$ & 1 & FJ528648 & FM897315 \\
\hline Stolonica socialis & Styelidae & $\begin{array}{l}\text { W Mediterranean and } \\
\text { NE Atlantic }\end{array}$ & $\begin{array}{l}\text { Algeciras, Spain } \\
\text { Plymouth, UK }\end{array}$ & $\begin{array}{l}36^{\circ} 06^{\prime} 47^{\prime \prime} \mathrm{N}, 05^{\circ} 26^{\prime} 02^{\prime \prime} \mathrm{W} \\
50^{\circ} 21^{\prime} 18^{\prime \prime} \mathrm{S}, 4^{\circ} 07^{\prime} 35^{\prime \prime} \mathrm{W}\end{array}$ & 2 & FJ528651 & $\begin{array}{l}\text { FM897316, } \\
\text { FM897317 }\end{array}$ \\
\hline Styela clava & Styelidae & NE Atlantic & Cantabria and Ferrol, Spain & $43^{\circ} 28^{\prime} 45^{\prime \prime} \mathrm{N}, 08^{\circ} 15^{\prime} 34^{\prime \prime} \mathrm{W}$ & 2 & $\begin{array}{l}\text { FJ528635, } \\
\text { FJ528636 }\end{array}$ & FM897318 \\
\hline Styela gibbsii & Styelidae & NE Pacific & Cape Arago, Oregon, USA & $43^{\circ} 16^{\prime} 37^{\prime \prime} \mathrm{N}, 124^{\circ} 27^{\prime} 28^{\prime \prime} \mathrm{W}$ & 1 & FJ528637 & FM897319 \\
\hline Styela montereyensis & Styelidae & NE Pacific & Cape Blanco, Oregon, USA & $42^{\circ} 50^{\prime} 10^{\prime \prime} \mathrm{N}, 124^{\circ} 33^{\prime} 40^{\prime \prime} \mathrm{W}$ & 1 & FJ528638 & FM897320 \\
\hline Styela plicata & Styelidae & $\begin{array}{l}\text { NE Atlantic, NW } \\
\text { Mediterranean and SW } \\
\text { Pacific }\end{array}$ & Ferrol, Spain & $43^{\circ} 28^{\prime} 45^{\prime \prime} \mathrm{N}, 08^{\circ} 15^{\prime} 34^{\prime \prime} \mathrm{W}$ & 4 & $\begin{array}{l}\text { FJ528632, } \\
\text { FJ528636 }\end{array}$ & FM897321 \\
\hline & & & Barcelona, Spain & $41^{\circ} 22^{\prime} 29^{\prime \prime} \mathrm{N}, 02^{\circ} 11^{\prime} 01^{\prime \prime} \mathrm{E}$ & & FJ528631 & FM897322 \\
\hline & & & Lake Conjola, NSW, Australia & $35^{\circ} 15^{\prime} 39^{\prime \prime} \mathrm{S}, 150^{\circ} 26^{\prime} 44^{\prime \prime} \mathrm{E}$ & & $\begin{array}{l}\text { FJ528634 } \\
\text { FJ528633 }\end{array}$ & FM897323 \\
\hline Styela sp. 1 & Styelidae & W Indian & Mafia I., Tanzania & $07^{\circ} 39^{\prime} 08^{\prime \prime} \mathrm{S}, 39^{\circ} 55^{\prime} 07^{\prime \prime} \mathrm{E}$ & 1 & FJ528639 & FM897324 \\
\hline Styela sp. 2 & Styelidae & NE Atlantic & Plymouth, UK & $50^{\circ} 21^{\prime} 18^{\prime \prime} \mathrm{S}, 4^{\circ} 07^{\prime} 35^{\prime \prime} \mathrm{W}$ & 1 & FJ528640 & FM897325 \\
\hline
\end{tabular}

set 9 additional sequences of $\mathrm{COI}$ and 19 sequences of $18 \mathrm{~S}$ rDNA of species of Pyuridae and Styelidae from Genbank (see Table 2). In total, 31 species of Styelidae and 24 of Pyuridae were included in the analyses.

\subsection{DNA extraction, amplification}

Total DNA was extracted using a CTAB buffer method (2\%CTAB; 1.4 M NaCl; 20 mM EDTA; 100 mM Tris- $\mathrm{HCl}$ pH 8.0) (Doyle and 
Table 2

Sequences of Pyuridae and Styelidae obtained from Genbank. Species, family assignment and Accesion numbers indicated. *Sequences obtained from http:// www.berkeley.edu/archdata/Pyura.html.

\begin{tabular}{|c|c|c|c|}
\hline \multirow[t]{2}{*}{ Species } & \multirow[t]{2}{*}{ Family } & \multicolumn{2}{|c|}{ Accession number } \\
\hline & & $\mathrm{COI}$ & $18 \mathrm{~S}$ rDNA \\
\hline Boltenia villosa & Pyuridae & & AY903924 \\
\hline Halocynthia igaboja & Pyuridae & & AY903925 \\
\hline Halocynthia roretzi & Pyuridae & AB024528 & AB013016 \\
\hline Herdmania curvata & Pyuridae & & AF165827 \\
\hline Pyura chilensis & Pyuridae & *(3 sequences) & \\
\hline Pyura haustor & Pyuridae & & AY903926 \\
\hline Pyura mirabilis & Pyuridae & & $\begin{array}{l}\text { AJ250773 } \\
\text { AF165828 }\end{array}$ \\
\hline Pyura praeputialis & Pyuridae & *(3 sequences) & \\
\hline Pyura vittata & Pyuridae & & AJ250772 \\
\hline Botrylloides planus & Styelidae & & DQ346653 \\
\hline Botryllus tyreus & Styelidae & DQ365851 & \\
\hline Cnemidocarpa clara & Styelidae & & AJ250775 \\
\hline Cnemidocarpa finmarkiensis & Styelidae & & L12413 \\
\hline Dendrodoa aggregata & Styelidae & & AJ250774 \\
\hline Metandrocarpa taylori & Styelidae & & AY903922 \\
\hline Pelonaia corrugata & Styelidae & & L12440 \\
\hline Polycarpa papillata & Styelidae & & DQ346654 \\
\hline Polycarpa pomaria & Styelidae & L12441 & L12441 \\
\hline Polyandrocarpa misakiensis & Styelidae & & AF165825 \\
\hline Symplegma reptans & Styelidae & & DQ346655 \\
\hline Symplegma viridae & Styelidae & & DQ346655 \\
\hline
\end{tabular}

Doyle, 1987) including two chloroform-isoamyl extractions from ethanol preserved siphon tissues or complete zooids. Universal primers LCO1490 and HCO2198 described in Folmer et al. (1994) were used for the amplification of a fragment of the Cytochrome c Oxidase subunit I (COI) mitochondrial gene. In Stolonica socialis, due to failure of amplification, a new pair of specific primers, StCOIF $5^{\prime}$ CGTATGGAGTTGTCCCAGGT $3^{\prime}$ and St-COIR $5^{\prime}$ AGCCCT CATCCTTTGCTCTT $3^{\prime}$, were designed with the program PRIMER 3.0 (available at http://primer3.sourceforge.net/, verified April 2007) from a sequence of the species Symplegma rubra. For amplification of a fragment of $18 \mathrm{~S}$ rDNA gene we used the primers 18S-TF and 18S-TR described in Carreras-Carbonell et al. (2005).

PCRs were performed in a $20 \mu \mathrm{l}$ total reaction volume with $0.5 \mu \mathrm{l}$ of each primer $(10 \mu \mathrm{M}), 0.5 \mu \mathrm{l}$ dNTPs $(10 \mu \mathrm{M}), 4 \mu \mathrm{l} 5 \times$ buffer, $1.6 \mu \mathrm{MgCl}_{2}$ (Promega: www.promega.com), $0.2 \mu \mathrm{l}$ FlexiTaq polymerase (Promega) and $0.5 \mu \mathrm{l}$ template DNA. A single soak at $94{ }^{\circ} \mathrm{C}$ for 2 min was followed by 35 cycles (denaturation at $94^{\circ} \mathrm{C}$ for $45 \mathrm{~s}$, annealing at specific temperatures (see below) for $50 \mathrm{~s}$, and extension at $72{ }^{\circ} \mathrm{C}$ for $55 \mathrm{~s}$ ) and a final extension at $72{ }^{\circ} \mathrm{C}$ for 5 min on a PCT-200 DNA Engine Peltier Thermal Cycler. Annealing temperature was different for each gene to obtain adequate amplification $\left(45^{\circ}-49^{\circ}\right.$ for $\mathrm{COI}$ and $66^{\circ}$ for $\left.18 \mathrm{~S}\right)$. The same primers were used for the sequencing reaction, and the PCR products were sequenced using the ABI Big-Dye Ready-Reaction Perkin Elmer kit on an ABI Prism 377XL automated sequencer, Applied Biosystems (www.appliedbiosystems.com).

\subsection{Alignment and phylogenetic analyses}

Sequences were edited using Bioedit Sequence Alignment Editor v 7.0.5.2 (Hall, 1999). Alignment of the ascidian COI mtDNA and 18S rDNA sequences was performed using Clustal W (Thompson et al., 1994) and confirmed by eye. No gaps were needed in the alignment of COI sequences, and there were no stop codons. The final sequence length was $685 \mathrm{bp}$. Codon position assignment and amino acid translation were obtained using MEGA v 3.0 (Kumar et al., 2004). There were a few gaps in the $18 \mathrm{~S}$ rDNA and the final sequence alignment (gaps included) was $821 \mathrm{bp}$. All sequences have been deposited in EMBL (available at www.ebi.ac.uk/embl/, accession numbers in Table 1 ).
For the phylogenetic analyses, we included sequences of the ascidian Ciona intestinalis as an outgroup (acc. numbers AK116803 and AB013017 for COI and 18S, respectively). We purposefully did not consider Molgulidae as an outgroup in this work because their relationships with Styelidae and Pyuridae are not clear (they are close on morphological grounds to Pyuridae, Berrill, 1950) and because they represent long branches (Huber et al., 2000). Indeed, in preliminary trials with molgulid species and Cio$n a$, the Molgulidae had the longest branches and appeared basally, leaving Ciona in the ingroup, a result clearly inconsistent with well established phylogenies.

For phylogenetic reconstruction, both maximum likelihood (ML) and Bayesian inference (BI) methods were applied separately for sequences of $\mathrm{COI}$ and $18 \mathrm{~S}$. Individual data sets of $\mathrm{COI}$ and $18 \mathrm{~S}$ rDNA were also concatenated for a total evidence analysis. We also tried two analytical strategies for the COI gene: using a single model for the gene or separate models for the first, second and third codon position.

Topological incongruence among genes was tested using the incongruence length difference (ILD) test using PAUP (Farris et al., 1994; Swofford, 2002). In this test, 6000 heuristic searches were carried out after the removal of all invariable characters from the data set. Topological differences were considered significant if two different relationships for the same set of taxa were both supported with bootstrap values $>70 \%$ or posterior probability values $>95 \%$. To check the possibility of the COI gene being saturated, we plotted the uncorrected $p$-distances between all pairs of specimens against the number of substitutions considering transitions and transversions separately.

For Maximum Likelihood (ML) and Bayesian inference (BI), the best-fit models of nucleotide substitution were selected by statistical comparison of 56 different models of evolution with the program Modeltest 3.0 (Posada and Crandall, 1998) with the Akaike Information Criterion (AIC). For Maximum Likelihood the models selected were then input into Treefinder (June 2008 version) (Jobb et al., 2004) and analyzed. The appropriate partitions were defined for the total evidence analyses and for the separation of codon positions in COI. Rate heterogeneity was selected in all the models chosen (see Section 3), and five rate categories were used in the calculations. The remaining settings of the program were left at default values. Nodal supports were assessed by 100 bootstrap replicates. For Bayesian inference analyses we used MrBayes v3.1.2 (Huelsenbeck and Ronquist, 2001). Values of the evolution models selected were input and runs of 3 million generations were executed with a sample frequency of 100 (30,000 trees). After verifying that stationarity had been reached, both in terms of likelihood scores and parameter estimation, the first 3000 trees were discarded, and independent majority-rule consensus trees were generated from the remaining (post-burnin) trees.

For all analyses mentioned previously, gaps of the 18S rDNA gene were treated as missing data. However, in recent years, several studies have pointed out that indels/gaps (resulting from insertion/mutation events) can contain useful information for phylogenetic reconstruction (see Ogden and Rosenberg, 2007 for a review). Due to presence of insertions/deletions within our 18S rDNA data set, we compared BI trees obtained treating gaps as either missing data or codified data following the "simple indel coding" method. This method, implemented by the software GapCoder (Young and Healy, 2003), codes indels as separate characters in a data matrix in which each indel with different start or end position is considered to be a separate character.

Phylogenetic analysis of the COI amino acid data was also conducted using the Bayesian Inference method in MrBayes. In order to estimate the best evolutionary model for our data we used and compared two different systems: the software Prottest and a MCMC sampler in MrBayes. The program Prottest estimates the 
empirical model of amino acid substitution that best fits the data among 64 candidate models. In addition, a MCMC sampler was run to explore all the fixed models implemented in MrBayes. The contribution of every model to the posterior probability allows the estimation of the best model among them. The model of amino acid substitution mtREV for mtDNA was estimated as the best model for our dataset under both approaches. The evolution model selected, mtREV, was then input in MrBayes and runs of 3 million generations were executed with a sample frequency of 100 and the first 3000 trees discarded.

\section{Results}

\subsection{Sequence saturation for $\mathrm{COI}$}

A fragment of $685 \mathrm{bp}$ from COI was compared for 62 sequences. We found 350 parsimony informative sites. Of the nucleotide substitutions, $24.8 \%$ occurred at first position, $4.8 \%$ at second position and $69.8 \%$ at third position, with an overall transition/transversion ratio of 1 in the last position. The plots of uncorrected $p$-distances against number of substitutions showed that there is no strong signal of saturation for COI in our dataset (results not shown).

\subsection{Phylogenetic analysis}

In the Modeltest procedure, the AIC confirmed that the $\mathrm{GRT}+\mathrm{G}+\mathrm{I}$ was the best-fit model for COI (685 bp) and the $\operatorname{TrN}+\mathrm{G}+\mathrm{I}$ was the best-fit model among those evaluated for $18 \mathrm{~S}$ rDNA sequences ( $821 \mathrm{bp}$ ). When the COI gene was partitioned as per codon position, the three models selected were GTR $+G$, $\operatorname{TvM}+\mathrm{G}+\mathrm{I}$ and $\mathrm{TrN}+\mathrm{I}+\mathrm{G}$ for first, second and third codon positions, respectively. The parameters of all the models are given in Table 3.

Figs. 1 and 2 show the resulting relationships of the 61 sequences ( 54 species) analyzed for $18 \mathrm{~S}$ rDNA and the 61 sequences (33 species) for COI, plus Ciona intestinalis as outgroup in both cases. The different analytical methods yielded the same topology for each gene. The comparison between 18S rDNA trees reconstructed treating gaps as either missing data or codified data did not show any substantial difference in topology and branch support, so we only include the results with gaps treated as missing data. In the COI gene, the codon-partitioned analysis gave essentially the same results as the one model analysis, and only the latter is shown in Fig. 2. A phylogenetic analysis (BI) of the COI amino acid data did not provide any additional information compared to the phylogenetic tree of the COI sequences and is therefore not shown. Fig. 3 shows the phylogenetic tree resulting from the total evidence analysis using $1506 \mathrm{bp}$ of concatenated sequences of $18 \mathrm{~S}$ and COI (77 sequences, 55 species) with a single model for COI. The species Pyura chilensis was discarded because it resulted in long branches in the total evidence analysis. The analysis with codonpartitioned models gave essentially the same results but the tree was somewhat less resolved due to lower nodal support values. The posterior probabilities and bootstrap support values of the clades (using one model or partitioned models for COI where applicable) are indicated in the corresponding figures.

The phylogenetic trees based on the 18S rDNA and COI data presented different topologies, with both fragments showing higher support on the tips of the clades (Figs. 1 and 2), and significant incongruence $\left(P_{\mathrm{ILD}}=0.03\right)$ was found between the phylogenetic information given by the nuclear fragment of $18 \mathrm{~S}$ rDNA and the mitochondrial COI.

\subsection{The monophyletic Pyuridae}

Sequences of the 18S rDNA and COI always recovered members of Pyuridae within the same clade. Monophyly of the family Pyuridae, here represented by species of the genera Boltenia, Halocynthia, Herdmania, Pyura and Microcosmus, had posterior probabilities of $0.99,0.74(0.91)$ and 0.95 (0.95) for 18S rDNA, $\mathrm{COI}$, and $\mathrm{COI}+18 \mathrm{~S}$, respectively (values in brackets correspond to models partitioned by codon position). Bootstrap supports, however, were considerably lower. The nuclear and mitochondrial sequences reconstructed different phylogenetic relationships among the genera belonging to this family (Figs. 1-3).

All the analyses showed the genus Pyura as a polyphyletic group within the Pyuridae. Species of this genus split into several clades. The most robust of these clades, including the Pacific species Pyura spinifera, Pyura gibbosa, Pyura australis and Pyura praeputialis, was well-supported in BI and ML analyses of $18 \mathrm{~S}$ rDNA and the combined dataset, while an unresolved polytomy appeared in the COI analysis. This group was related to the clade of Herdmania species. The remaining Pyura species formed different clades that were not consistent among the analyses, reinforcing the idea that the genus is polyphyletic. The grouping of Herdmania and Pacific species of Pyura suggests close relationships between these genera. The genera Microcosmus, Boltenia, Herdmania and Halocynthia appeared as monophyletic (with posterior probabilities always higher than 0.8 ), except for the fact that the COI sequence of Pyura squamulosa joined the Microcosmus clade, probably as a result of an excess of homoplasy on the third codon position due to the high level of variation on this gene (Fig. 2).

\subsection{The paraphyletic Styelidae}

The family Styelidae, as traditionally described, seems to be a paraphyletic group judging from the phylogenies obtained with Ciona as an outgroup. The groupings of genera, however, were somewhat different depending on the gene studied, with some conflicting clades (see Fig. 1 and 2) and a general lack of resolution.

Two main clades appeared in all trees: one comprising the Styela species (together with Pelonaia and Cnemidocarpa in $18 \mathrm{~S}$ rDNA and total evidence trees), which appeared as a sister clade to the Pyuridae in the COI and the total evidence analyses. The second clade comprised the Botryllinae genera Botryllus and Botrylloides together with the Polyzoinae Symplegma. The remaining Styelidae formed a few unresolved clades that branched more or less basally and that comprised both colonial (Stolonica, Polyzoa,

Table 3

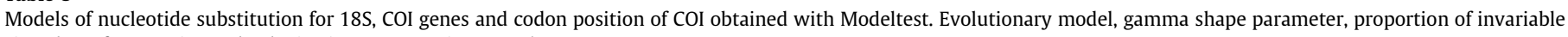
sites, base frequencies and substitution rate matrices are shown.

\begin{tabular}{|c|c|c|c|c|c|c|c|c|c|c|c|c|c|}
\hline \multirow[t]{2}{*}{ Gene } & \multirow[t]{2}{*}{ Model } & \multirow[t]{2}{*}{ Gamma } & \multirow[t]{2}{*}{ Inv. sites } & \multicolumn{4}{|c|}{ Base frequencies } & \multicolumn{6}{|c|}{ Substitution rate matrices } \\
\hline & & & & A & $\mathrm{C}$ & G & $\mathrm{T}$ & $A-C$ & $A-G$ & A-T & $C-G$ & $\mathrm{C}-\mathrm{T}$ & $\mathrm{G}-\mathrm{T}$ \\
\hline $18 \mathrm{~S}$ & $\operatorname{TrN}+\mathrm{I}+\mathrm{G}$ & 0.566 & 0.7561 & 0.2652 & 0.2168 & 0.2856 & 0.2324 & 1 & 1.3647 & 1 & 1 & 5.921 & 1 \\
\hline COI & $\mathrm{GTR}+\mathrm{I}+\mathrm{G}$ & 0.2841 & 0.2479 & 0.2756 & 0.0715 & 0.2159 & 0.4370 & 4.745 & 33.331 & 2.252 & 9.033 & 57.241 & 1 \\
\hline $1^{\circ}$ & $\mathrm{GTR}+\mathrm{G}$ & 0.2317 & - & 0.2936 & 0.0919 & 0.2005 & 0.4141 & 2.792 & 13.632 & 1.388 & 0.926 & 37.035 & 1 \\
\hline $2^{\circ}$ & $\mathrm{TvM}+\mathrm{I}+\mathrm{G}$ & 0.6083 & 0.5491 & 0.1457 & 0.2062 & 0.1988 & 0.4493 & 1.857 & 2.860 & 1.50 & 9.490 & 2.860 & 1 \\
\hline $3^{\circ}$ & $\operatorname{TrN}+\mathrm{I}+\mathrm{G}$ & 0.6689 & 0.0100 & 0.2697 & 0.0553 & 0.2004 & 0.4747 & 1 & 65.971 & 1 & 1 & 107.963 & 1 \\
\hline
\end{tabular}




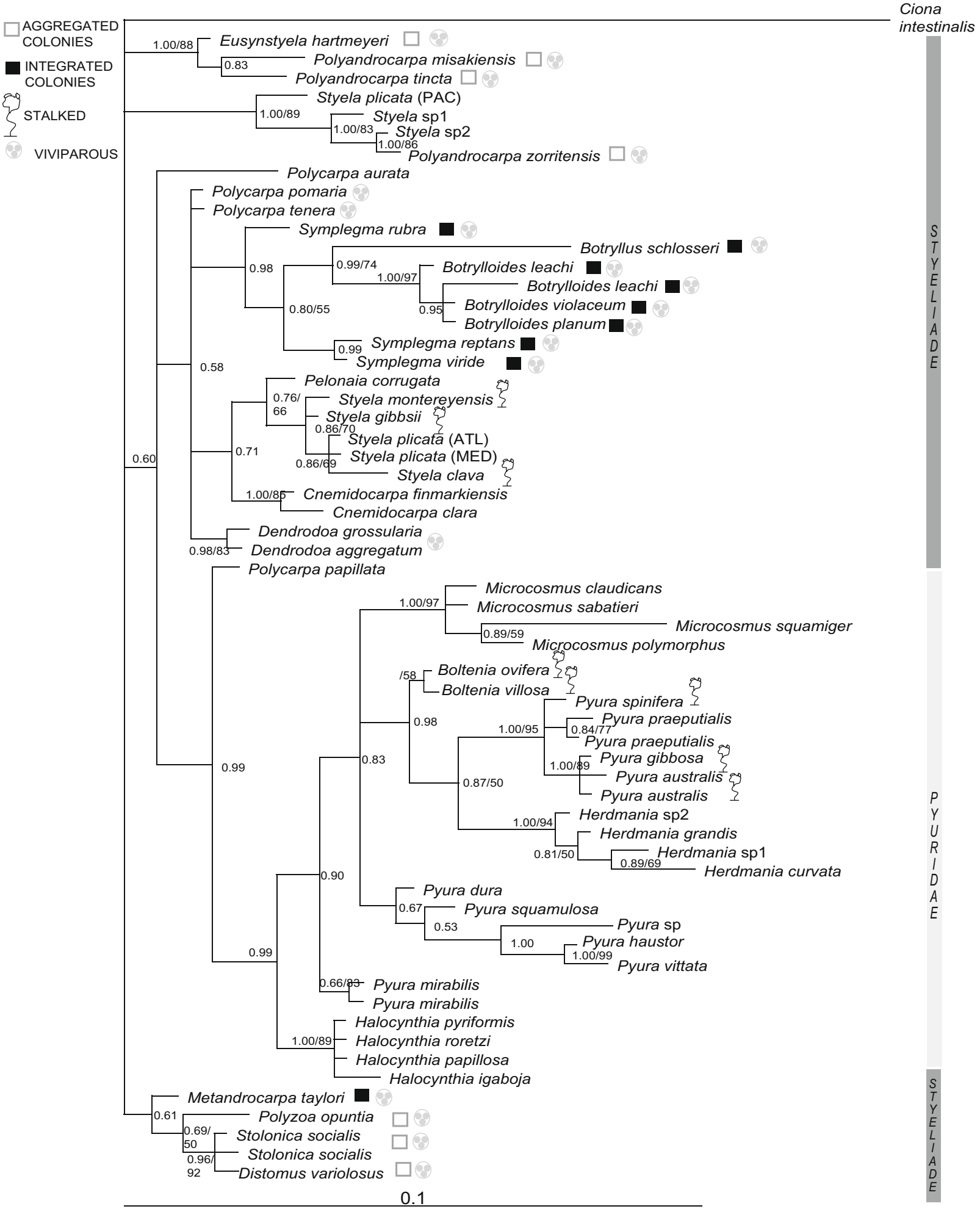

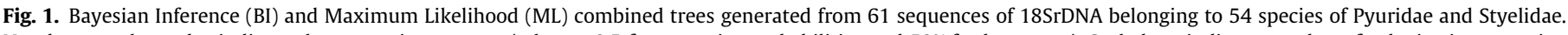

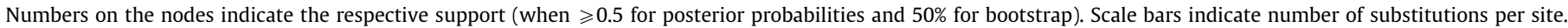
Family assignments and life-style features are shown.

Polyandrocarpa, Eusynstyela) and solitary (Dendrodoa, Polycarpa) genera.

The 18S rDNA sequence of Polyandrocarpa zorritensis appeared more closely related to some species of Styela than to the other two species of Polyandrocarpa included in the analyses, a result that may be due to the relatively long branch of this species. The genus Polycarpa appeared as a polyphyletic group, indicating that this genus, one of the most species of ascidians, comprises different evolutionary lineages. An unexpected finding is that specimens of Styela plicata grouped in two different clades for both nuclear and mitochondrial data with a high genetic divergence (24\% of nucleotide divergence for COI and $1.9 \%$ for $18 \mathrm{~S}$ rDNA). The Atlanto-Mediterranean Styela plicata formed a clade together with Styela clava, whereas the Pacific Styela plicata grouped with the 


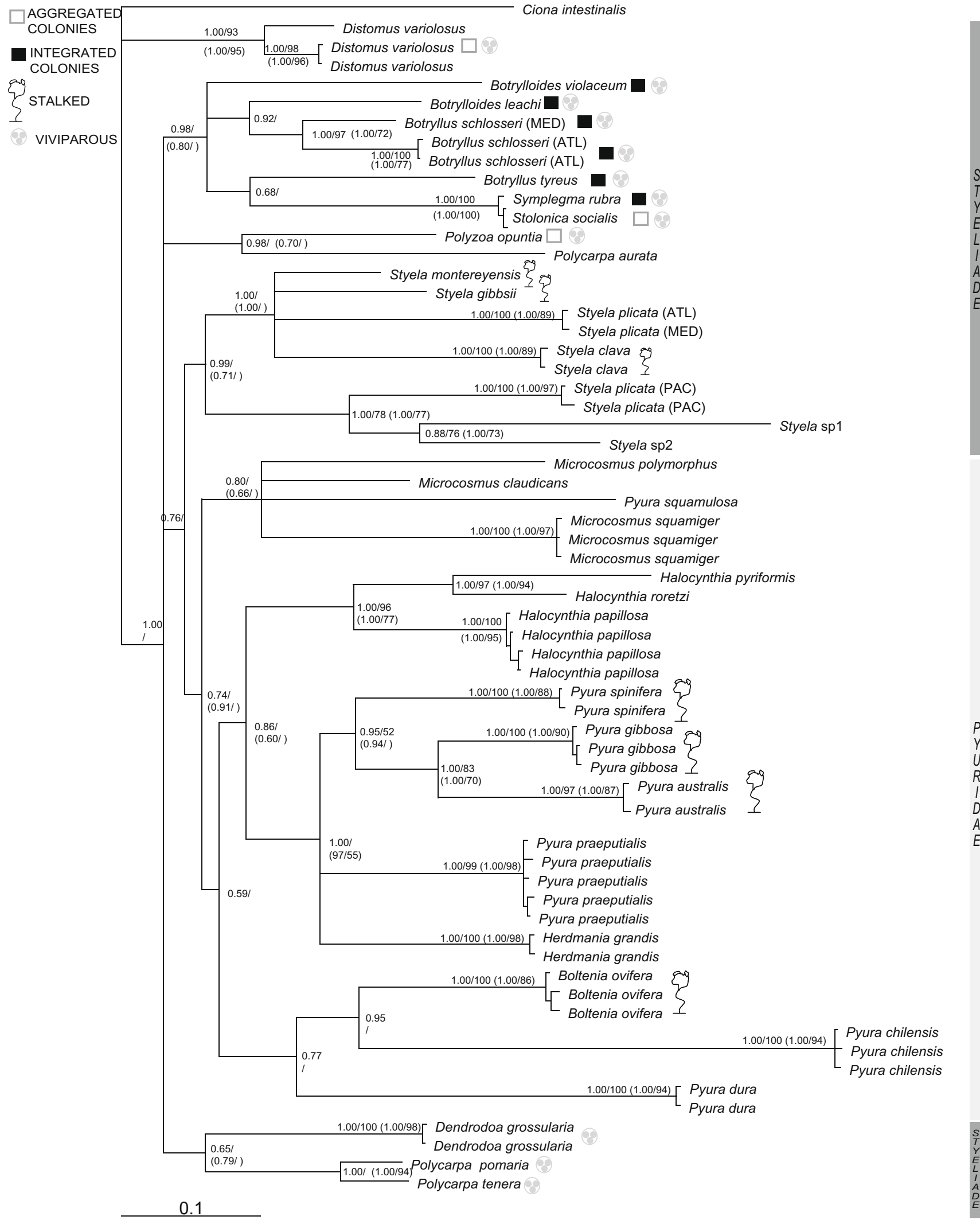

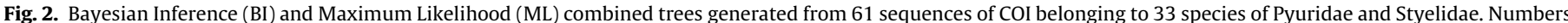

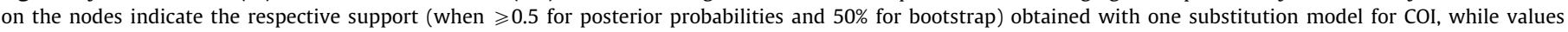

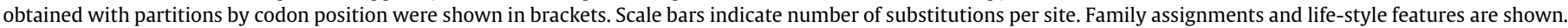

unidentified Styela sp. 1 and Styela sp.2 from the Indian and Atlantic Ocean. This result is consistent with the existence of two cryptic species with distinct geographic distributions within Styela plicata.
Concerning the relative position of colonial species in the cladograms, there were conflicting groups as a function of the gene used, but the clade of Botryllus and Botrylloides with Symplegma was al- 


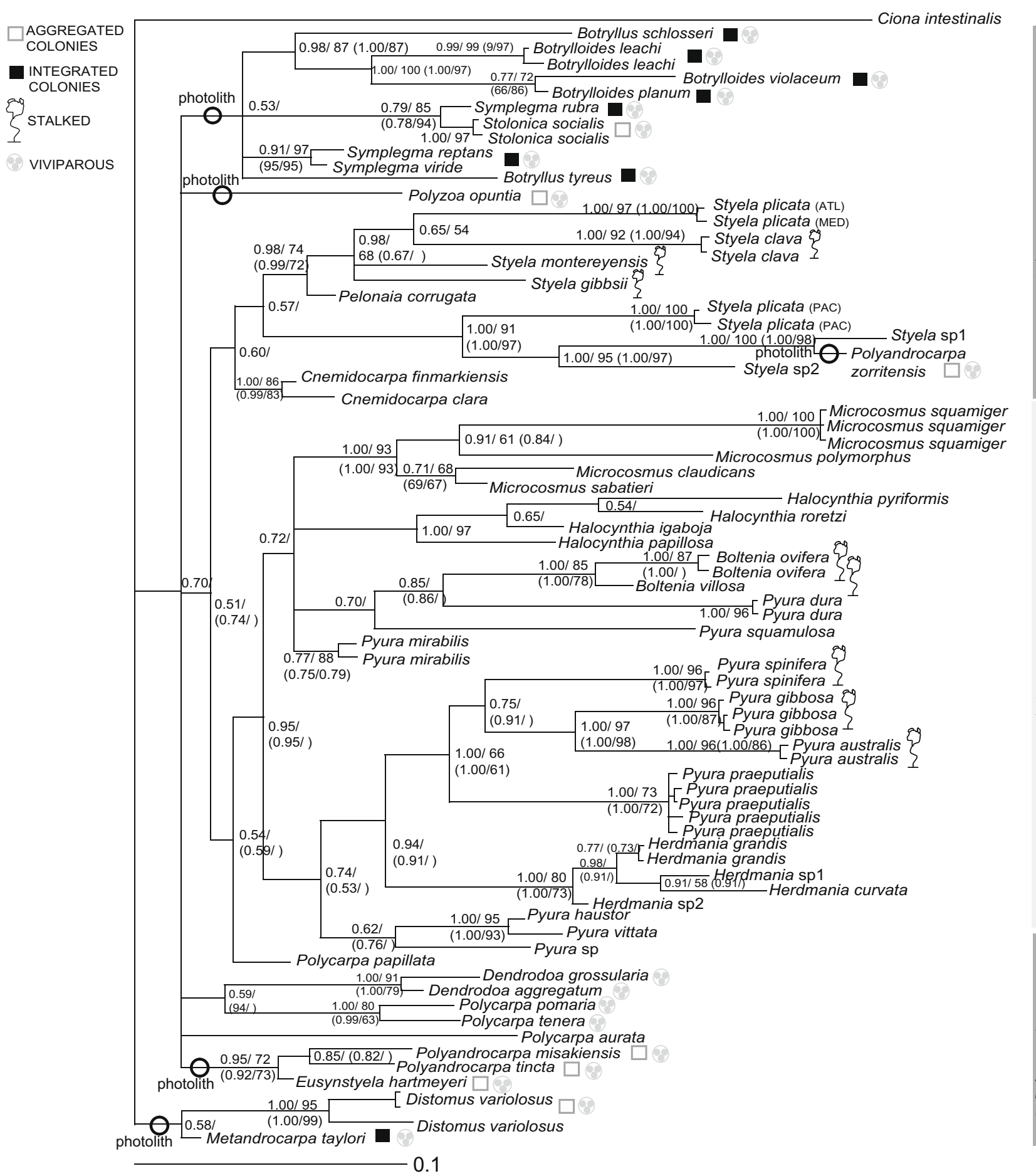

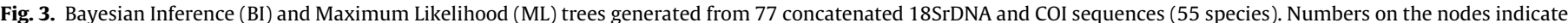

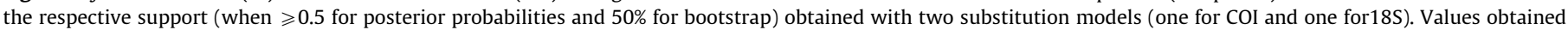

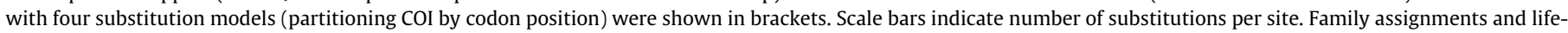
style features are shown.

ways recovered, a grouping that also included Stolonica in the COI and combined analyses. In the $18 \mathrm{~S}$ rDNA dataset the colonial species appeared in three main clades: the above-mentioned botryllid + Symplegma clade, a Metandrocarpa + Polyzoa + Stolonica + Distomus clade, and a Eusynstyela + Polyandrocarpa clade. In the COI and combined analyses, Distomus formed a clade that branched basally with respect to the other Styelidae and Pyuridae. Polyzoa ( $P$. opuntia) and Stolonica (S. socialis) had different positions according to the analysis. Metandrocarpa taylori appeared consistently related to the Distomus clade. Therefore, even if there was some disagreement between the different analyses, in no tree was a single clade of the colonial Styelidae found, and in all cases well-supported clades contained different lineages of colonial forms.

\section{Discussion}

In this study, we analyze the phylogeny of the families Pyuridae and Styelidae including a total of 31 Styelids (14 genera) and 24 
Pyurids ( 5 genera). The ILD test showed incongruence between the phylogenies obtained from $18 \mathrm{~S}$ rDNA and COI sequences. Such lack of coherence was also found by Stach and Turbeville (2002). These authors attributed it to a high mutation rate of COI, saturation of changes in this molecule, and the possible presence of nuclear pseudogenes of COI. In our dataset there was no clear signal of saturation. All the COI sequences included in our study could be translated into amino acids with no stop codons, and gaps were not necessary for the alignment, which suggests that the sequences do not correspond to pseudogenes. In contrast, we have found evidence for pseudogenes in some of the sequences obtained in Stach and Turbeville (2002) that were thus not used in this study. Therefore, incongruence between $18 \mathrm{~S}$ rDNA and COI phylogenies is not likely to be an artifact from saturation or pseudogene presence. Different gene trees can be affected by different histories of lineage sorting when there are deep coalescences (Maddison and Knowles, 2006; Kubatko and Degnan, 2007), which can hinder the inference of the true species tree. In addition, the different taxon sampling in both datasets can contribute to the lack of coherence found. On the other hand, different rates of mutation between mitochondrial and nuclear genes may explain several results, such as the particular phylogenetic position of Distomus variolosus in our trees. The only $18 \mathrm{~S}$ rDNA sequence found joined with other colonial species of Styelidae, as expected from its morphological features, but the three haplotypes of COI obtained for this species grouped in a basal clade separated from the other members of Pyuridae and Styelidae.

The order Stolidobranchiata including the families Molgulidae, Styelidae and Pyuridae forms a robust monophyletic clade in molecular studies (Swalla et al., 2000; Zeng and Swalla, 2005). These phylogenies split Stolidobranchiata in two main clades: the Molgulidae on one side and the Pyuridae and Styelidae on the other, in which Pyuridae tended to be paraphyletic and/or to appear basal to the Styelidae (Stach and Turbeville, 2002; Zeng and Swalla, 2005; Zeng et al., 2006). In contrast, our phylogenetic trees obtained from both nuclear and mitochondrial fragments and using a non-Molgulid outgroup (Ciona) recovered Pyuridae as a monophyletic clade with relatively high support and a derived position with respect to the styelids. The fact that Molgulidae have long branches (Huber et al., 2000) and that they are probably related to Pyuridae (Berrill, 1950) can explain that they appear basally in Stolidobranchiata and attract Pyuridae with them in the above-mentioned studies. Interestingly, in another study without Molgulidae (Turon and López-Legentil, 2004) the Pyuridae was also monophyletic. A more specific taxon sampling looking for slow evolving Molgulidae would be necessary to ascertain their position among stolidobranchs. We therefore contend that Pyuridae is a phylogenetically valid taxon although its internal arrangement remains inconclusive. The relative position of genera within the Pyuridae varied in our analyses except for a consistent grouping of Herdmania with some Pacific species of Pyura. Other species of Pyura appeared in different clades. Our results suggest, therefore, that the genus Pyura, as currently described, is polyphyletic.

The members of the large family Styelidae have been classified according to different (and conflicting) schemes. One arrangement divided Styelidae into two subfamilies, Styelinae, including nonbudding solitary styelids, and Botryllinae, including only budding colonial species (Berrill, 1950). Other authors have raised these subfamilies, with the same or different names, to family-level (see Berrill, 1950, for a review). Still other authors (e.g. Nishikawa, 1991) consider another arrangement into two separate families, Botryllidae including only the colonial species that form systems of zooids, and Styelidae including the remaining species (solitary or colonial). Kott (1985), in her recent revision of the family, adopted the division of Styelidae into three subfamilies: Styelinae, Polyzoinae and Botryllinae. The subfamily Styelinae includes all the solitary members that do not reproduce vegetatively. The subfamily Polyzoinae comprises colonial members with asexual reproduction but in which zooids open separately to the exterior and never form colonial systems. The Botryllinae are distinguished by their zooids embedded in common tunic and arranged in systems (only Botryllus and Botrylloides comprise this subfamily). Reconciling phylogenetic trees with traditional taxonomic schemes of ascidians has proven difficult on occasions (see examples in Turon and López-Legentil, 2004 and Pérez-Portela and Turon, 2008), but evolutionary studies can uncover new relationships among taxa that, once properly validated, should be included in classification schemes. For instance, our results show that the current systematic arrangements of Styelidae are invalid, as some genera of Styelinae sensu Kott (e.g. Polycarpa, Dendrodoa, see Fig. 1) were more closely related to colonial forms than others (e.g. Styela), while Polyzoinae species appeared in different branches of our cladograms. Only the Botryllinae (here represented by four species) formed a consistently monophyletic group, closely related to the polyzoinid genus Symplegma.

Our results show a consistent grouping of solitary, non viviparous forms (Styela, Pelonaia, Cnemidocarpa), while other solitary genera (Polycarpa and Dendrodoa, both with at least some viviparous species) and the colonial species form different clades. The relationships among these clades varied according to the analysis, but in all cases they indicated a repeated evolution of coloniality from the solitary forms. The colonial Polyzoa appeared in an unstable position in our trees, either related to Polycarpa, to other colonial genera, or in an unresolved basal position. In addition, Polycarpa appeared in all trees as a polyphyletic taxon. The polyphyletic, parallel evolution of coloniality of Styelidae has been advocated by several authors (e.g. Kott, 1985, 2005) and seems justified by the morphological similarity between some colonial polyzoinid and solitary styelinid genera (Kott, 2005), as exemplified by the Polycarpa/Polyandrocarpa species (Monniot et al., 1991).

Further support for the idea that some solitary genera have the potential for vegetative reproduction come from observations of occasional budding by the solitary species Polycarpa comata (reported in Brien, 1948; Mukai et al., 1978) and Cnemidocarpa stolonifera (reported in Kott, 1995), by the capabilities of evisceration (followed by regeneration) of several species of Polycarpa, which may result in the formation of several zooids (Monniot, 1987). Furthermore, the recent description of a colonial Styela species, S. complexa (Kott, 1995), extends the range of independent acquisitions of coloniality and confirms the convergent nature of this character.

Perhaps the strongest case against this polyphyletic vision of coloniality was made by Berrill (1950), who considered that all colonial forms of Styelidae form a natural group on the basis of budding type and larval features. However, the ability for palleal budding may be a primitive characteristic of the family, as shown by the tendency of otherwise solitary species to produce buds (see above). The larval structure seems a more compelling argument for uniting all colonial species. Larvae of the solitary species have either a reduced ocellus (Styela) or no ocellus at all (Polycarpa, Dendrodoa), a fact that may be linked to the adaptation to open sea-floor habitats (Kott, 1985). In contrast, larvae of colonial species have developed a secondary photoreceptor organ, the photolith, which is a modified otolith (Grave and Riley, 1935; Berrill, 1949). However, a photolith, together with a reduced ocellus, was found in the larva of the solitary Cnemidocarpa finmarkiensis (Vorontsova and Malakhov, 1984), so this character may also be unreliable for establishing evolutionary lineages and may reflect a plesiomorphic ability to compensate the reduction or loss of the ocellus when ecological requirements make it necessary. This is coherent with the mapping of the species that have photolith in our total evidence tree (Fig. 3), which shows that this character was found in different lineages. 
The colonies with common vascular systems (integrated colonies) represent the highest degree of colonial adaptation, allowing colony specificity and allorecognition reactions (Watanabe and Taneda, 1982; Rinkevich, 2005). Most integrated colonies in our dataset appeared in the cladograms in a single clade that grouped Botryllinae and Symplegma (plus the aggregated species Stolonica socialis in the COI and total evidence trees). However, another genus with integrated colonies (Metandrocarpa) appeared in our trees in a different clade of colonial species. This may indicate that this degree of colonial integration appeared more than once in the evolution of Styelidae, although this point requires further analysis, given that we could not obtain COI sequences of Metandrocarpa.

When we mapped viviparity on our trees, it is significant that solitary genera (Polycarpa, Dendrodoa) that appeared more related to colonial forms (e.g. Fig. 1) have at least some viviparous species. Viviparity is often associated with colonial ascidians, with few exceptions (Svane and Young, 1989). Only the Styelidae, Agnesiidae, Molgulidae and Corellidae have instances of viviparous solitary species (Kott, 1985; Lambert et al., 1995). In Polycarpa, diverse features in gonads and gonoducts favor a longer retention of eggs and internal fertilization (Kott, 1985), possibly associated with the need to restrict dispersal in an open sea-floor environment. These features may have led to the development of viviparity in several species. Our phylogenetic trees suggest that the lineages that have evolved into colonial forms have viviparous species and, thus, that viviparity may somehow be a pre-adaptation for coloniality, rather than the converse.

The presence of stalks has appeared several times within Pyuridae and Styelidae, as expected given the adaptive nature of this character, but nevertheless some stalked forms are related and may stem from common stalked ancestors. Thus, the stalked Pyura species belonged to the Pyura + Herdmania clade, and appeared grouped in the $\mathrm{COI}$ and combined analyses, suggesting a possible common origin of this character. The stalked species Boltenia appeared related to the group containing stalked Pyura clade in the $18 \mathrm{~S}$ rDNA set, but not in the COI and combined analyses. In our sample of Styelidae, stalks were found in only a few Styela species, of which $S$. montereyensis and $S$. gibbsii are evolutionarily close relatives.

Our conclusions were hindered by the failure to amplify COI of important species, so only $18 \mathrm{~S}$ rDNA could be obtained for Eusynstyela hartmeyeri and Polyandrocarpa spp. In addition, parts of our trees were poorly resolved, and the placement and affinities of Distomus variolosus, Polyzoa opuntia and Polyandrocarpa zorritensis require further assessment. More solitary and colonial species should be included in future analyses to better resolve the internal phylogenetic relationships within these ascidian families and to confirm the point raised by this study concerning the origins of coloniality.

\section{Acknowledgments}

The Scientific and Technical Services of the University of Barcelona provided sequencing facilities and advice. Richard Emlet, Ana Riesgo, Adriana Villamor, Marc Rius, Noa Shenkar and PharmaMar S.A. (Madrid) kindly provided samples for the analyses. We cheerfully thank Dr Salvador Carranza for advice and help with the phylogenetic procedures. This research was supported by a postdoctoral grant from the Spanish foundation "Fundación Alfonso Martín Escudero (FUNDAME)", a FCT postdoctoral fellowship from the Portuguese Government (SFRH/BPD/41055/2007) and by project CTM2007-66635 of the Spanish Government and project 2007301026 (CSIC). This represents contribution no. 284 from the Ecology and Genetics Group at the University of Wollongong.

\section{References}

Abbot, D.P., 1953. Asexual reproduction in the colonial ascidian Metandrocarpa taylori Huntsman. Univ. Cal. Pub. Zool. 61, 1-78.

Berrill, N.J., 1949. The gonads, larvae, and budding of the Polystyelid ascidians Stolonica and Distomus. J. Mar. Biol. Ass. U.K. 27, 633-650.

Berrill, N.J., 1951. Regeneration and budding in Tunicates. Biol. Rev. 26, 456-475.

Berrill, N.J., 1950. The Tunicata. Ray Society, London.

Berrill, N.J., 1955. The Origin of Vertebrates. Oxford University Press, London.

Bishop, J.D.D., Sommerfeldt, A.D., 1999. Not like Botryllus: indiscriminate post-metamorphic fusion in a compound ascidian. Proc. R. Soc. Lond. 266, 241-248.

Blair, J.E., Hedges, S.B., 2005. Molecular clocks do not support the Cambrian explosion. Mol. Biol. Evol. 22, 387-390.

Bourlat, S.J., Nielsen, C., Lockyer, A.E., Littlewood, D.T., Telford, M.J., 2003. Xenoturbella is a deuterostome that eats molluscs. Nature (Lond.) 424, 925-928.

Bourlat, S.J., Juliusdottir, T., Lowe, C.J., Freeman, R., Aronowicz, J., Kirschner, M. Lander, E.S., Thorndyke, M., Nakano, H., Kohn, A.B., Heyland, A., Moroz, L.L., Copley, R.R., Telford, M.J., 2006. Deuterostome phylogeny reveals monophyletic chordates and the new phylum Xenoturbellida. Nature 444, 85-88.

Brien, P., 1948. Embranchement des Tuniciers. Morphologie et Reproduction. In: Grassé, P.P. (Ed.), Traité de Zoologie, Anatomie, Systématique, Biologie Tome XI. Échinodermes, Stomocordés, Procordés. Masson, Paris, pp. 554-930.

Cameron, C.B., Garey, J.R., Swalla, B.J., 2000. Evolution of the chordate body plan: new insights from phylogenetic analyses of deuterostome phyla. Proc. Natl. Acad. Sci. 87, 4469-4474.

Carreras-Carbonell, J., Macpherson, E., Pascual, M., 2005. Rapid radiation and cryptic speciation in mediterranean triplefin blennies (Pisces: Tripterygiidae) combining multiple genes. Mol. Phylogenet. Evol. 37, 751-761.

Delsuc, F., Brinkmann, H., Chourrout, D., Philippe, H., 2006. Tunicates and not cephalochordates are the closest living relatives of vertebrates. Nature 439, 965-968.

Doyle, J.J., Doyle, J.L., 1987. A rapid DNA isolation procedure for small quantities of fresh leaf tissue. Phytochem. Bull. 19, 11-15.

Dunn, C.W., Hejnol, A., Matus, D.Q., Pang, K., Browne, W.E., Smith, S.A., Seaver, E., Rouse, G.W., Obst, M., Edgecombe, G., Sorensen, M.V., Haddock, S.H.D., SchmidtRaesa, A., Okusu, A., Kristensen, R.M., Wheeler, W.C., Martindale, M.Q., Giribet, G., 2008. Broad phylogenomic sampling improves resolution of the animal tree of life. Nature 452, 745-750.

Farris, James S., Kallersjo, Mari, Kluge, Arnold G., Bult, Carol, 1994. Testing significance of incongruence. Cladistics 10, 315-319.

Folmer, O., Black, M., Hoeh, W., Lutz, R., Vrijenhoek, R., 1994. DNA primers for amplification of mitochondrial cytochrome c oxidase subunit I from diverse metazoan invertebrates. Mol. Mar. Biol. Biotechnol. 3, 294-299.

Garstang, W., 1928. The morphology of the Tunicata, and its bearings on the phylogeny of the Chordata. Quart. J. Micr. Sci. 72, 51-187.

Grave, C., Riley, G., 1935. Development of the sense organs of the larva of Botryllus schlosseri. J. Morphol. 57, 185-211.

Hadfield, K.A., Swalla, B.J., Jeffery, W.R., 1995. Multiple origins of anural development in ascidians inferred from rDNA sequences. J. Mol. Evol. 40, 413-427.

Hall, T.A., 1999. BioEdit: a user-friendly biological sequence alignment editor and analysis program for Windows 95/98/NT. Nucl. Acids Symp. Ser. 41, 95-98.

Huelsenbeck, J.P., Ronquist, F., 2001. MRBAYES: Bayesian inference of phylogenetic trees. Bioinformatics 17, 754-755.

Huber, J.L., Burke da Silva, K., Bates, W.R., Swalla, B.J., 2000. The evolution of anural larvae in molgulid ascidians. Cell Dev. Biol. 11, 419-426.

Jobb, G., Von Haeseler, A., Strimmer, K., 2004. TREEFINDER: a powerful graphical analysis environment for molecular phylogenetics. BMC Evol. Biol. 28, 4-18.

Kott, P., 1985. The Australian Ascidiacea Part I, Phlebobranchia and Stolidobranchia. Mem. Qld. Mus. 23, 1-440.

Kott, P., 1989. Form and function in the Ascidiacea. Bull. Mar. Sci. 45, 253-276.

Kott, P., 1995. A new colonial Styela (Ascidiacea: Styelidae) from an isolated marine habitat, Kakaban Island, East Kalimantan, Indonesia. Raffles Bull. Zool. 43, 469474.

Kott, P., 2005. Novel Australian Polyzoinae (Styelidae, Tunicata). J. Nat. Hist. 39, 2997-3011.

Koyama, H., Watanabe, H., 1986. Studies of the fusion reaction in two species of Perophora (Ascidiacea). Mar. Biol. 92, 267-275.

Kubatko, L.S., Degnan, J.H., 2007. Inconsistency of phylogenetic estimates from concatenated data under coalescence. Syst. Biol. 56, 17-24.

Kumar, S., Tamura, K., Nei, M., 2004. MEGA3: integrated software for molecular evolutionary genetics analysis and sequence alignment. Brief. Bioinform. 5, $150-163$.

Lambert, C.C., Lambert, I.M., Lambert, G., 1995. Brooding strategies in solitary ascidians-Corella species from north and south temperate waters. Can. J. Zool. 73, 1666-1671.

Maddison, W.P., Knowles, L.L., 2006. Inferring phylogeny despite incomplete lineage sorting. Syst. Biol. 55, 21-30.

Milne Edwards, M., 1841. Observations sur les ascidies composées des côtes de la Manche. Mem. Acad. Sci. Paris 18, 217-326.

Monniot, C., 1987. Ascidies de Nouvelle-Calédonie II. Les genres Polycarpa et Polyandrocarpa. Bul. Mus. Natn. Hist. Nat., Paris, 4e sér. 9, 275-310.

Monniot, C., Monniot, F., Laboute, P., 1991. Coral Reef Ascidians of New Caledonia. ORSTOM, Paris. p. 247 
Mukai, H., Sugimoto, K., Taneda, Y., 1978. Comparative studies on the circulatory system of the compound ascidians, Botryllus, Botrylloides and Symplegma. J. Morphol. 157, 49-78.

Nakauchi, M., 1982. Asexual development of ascidians: its biological significance, diversity, and morphogenesis. Am. Zool. 22, 753-763.

Nishikawa, T., 1991. The ascidians of the Japan Sea II. Publ. Seto Mar. Biol. Lab. 35, 25-170.

Ogden, H.T., Rosenberg, M.S., 2007. How should gaps be treated in parsimony? A comparison of approaches using simulation. Mol. Phylogenet. Evol. 42, 817-826.

Pérez-Portela, R., Turon, X., 2008. Phylogeny of the Clavelinidae, Ascidiacea, inferred from mtDNA data. Invert. Biol. 127, 108-120.

Pérez-Portela, R., Duran, S., Palacín, C., Turon, X., 2007. The genus Pycnoclavella (Ascidiacea) in the Atlanto-Mediterranean region: a combined molecular and morphological approach. Invert. Syst. 21, 187-205.

Philippe, H., Lartillot, N., Brinkmann, H., 2005. Multigene analyses of Bilateria corroborate the monophyly of Ecdysozoa, Lophotrochozoa, and Protostomia. Mol. Biol. Evol. 22, 1246-1253.

Posada, D., Crandall, K.A., 1998. MODELTEST: testing the model of DNA substitution. Bioinformatics 14, 817-818.

Rinkevich, B., 2005. Natural chimerism in colonial urochordates. J. Exp. Mar. Biol. Ecol. 322, 93-109.

Satoh, N., 1994. Developmental Biology of Ascidians. Cambridge University Press, Cambridge.

Stach, T., Turbeville, J.M., 2002. Phylogeny of Tunicata inferred from molecular and morphological characters. Mol. Phylogenet. Evol. 25, 408-428.

Svane, I., Young, C.M., 1989. The ecology and behaviour of ascidian larvae. Oceanogr. Mar. Biol. Annu. Rev. 27, 45-90.

Swalla, B.J., Cameron, C.B., Corley, L.S., Garey, J.R., 2000. Urochordates are monophyletic within the deuterostomes. Syst. Biol. 49, 52-64.

Swofford, D.L., 2002. 'PAUP*, Phylogenetic Analysis Using Parsimony (*and Other Methods).' Version 4, Sinauer Associates: Sunderland, MA, USA

Thompson, J.D., Higgins, D.G., Gibson, T.J., 1994. CLUSTAL W: improving the sensitivity of progressive multiple sequence alignment through sequence weighting, positions-specific gap penalties and weight matrix choice. Nucleic Acids Res. 22, 4673-4680.
Turbeville, J.M., Schulz, J.R., Raff, R.A., 1994. Deuterostome phylogeny and the sister group of the chordates: evidence from molecules and morphology. Mol. Biol. Evol. 11, 648-655.

Turon, X., López-Legentil, S., 2004. Ascidian molecular phylogeny inferred from mtDNA data with emphasis on the Aplousobranchiata. Mol. Phylogenet. Evol 33, 309-320.

Van Name, W.G., 1921. Budding in compound ascidians and other invertebrates, and its bearing on the question of the early ancestry of the vertebrates. Bull. Am. Mus. Nat. Hist. 44, 275-282.

Vorontsova, M.N., Malakhov, V.V., 1984. Anatomy and fine structure of larvae in Cnemidocarpa finmarkiensis (Ascidia). 2. Sense organs. Zoologicheskyi Zur. 68, 1036-1045.

Wada, H., 1998. Evolutionary history of free-swimming and sessile lifestyles in Urochordates as deduced from 18SrDNA molecular phylogeny. Mol. Biol. Evol $15,1189-1194$

Wada, H., Makabe, K.W., Nakauchi, M., Satoh, N., 1992. Phylogenetic relationships between solitary and colonial ascidians, as inferred from the sequences of the central region of their respective $18 \mathrm{~S}$ rDNAs. Biol. Bull $183,448-455$.

Watanabe, H., Newberry, A.T., 1976. Budding by oozooids in the Polystyelid ascidian Metandrocarpa taylori Hunstman. J. Morphol. 148, 161-176.

Watanabe, H., Taneda, Y., 1982. Self or non-self recognition in compound ascidians. Am. Zool. 22, 775-782.

Winchell, C.J., Sullivan, J., Cameron, C.B., Swalla, B.J., Mallatt, J., 2002 Evaluating hypotheses of deuterostome phylogeny and chordate evolution with new LSU and SSU ribosomal DNA data. Mol. Biol. Evol. 19, 762-776.

Young, C.M., Braithwaite, L.F., 1980. Orientation and current-induced flow in the stalked ascidian Styela montereyensis. Biol. Bull. 159, 428-440.

Young, N.D., Healy, J., 2003. GapCoder automates the use of indel characters in phylogenetic analysis. BMC Bioinformatics 4,6 .

Zeng, L., Swalla, B.J., 2005. Molecular phylogeny of the protochordates: chordate evolution. Can. J. Zool. 83, 24-33.

Zeng, L., Jacobs, M.W., Swalla, B.J., 2006. Coloniality has evolved once in Stolidobranch Ascidians. Integr. Comp. Biol. 46, 255-268. 